Individualized HRM and Organizational Performance 1

Age-related Differences in the Relations between Individualized HRM and Organizational Performance: A Large-Scale Employer Survey

P. MATTHIJS BAL

University of Bath

\title{
LUC DORENBOSCH
}

TNO $\mid$ Research Institute for Work \& Employment

Correspondence should be addressed to: Matthijs Bal, School of Management, University of Bath, BA2 7AY, United Kingdom. Email: p.m.bal@bath.ac.uk, 0044.1225-383143. 
Age-related Differences in the Relationship between Individualized HRM and Organizational Performance: A Large-Scale Employer Survey

\begin{abstract}
The current study aimed to investigate the relationship between individualized HRM practices and several measures of organizational performance, including the moderating role of employee age in these relationships. A large-scale representative study among 4,591 organizations in the Netherlands showed support for the relationships between individualized HR practices with organizational performance. Employee age moderated the relationships between the use of individualized practices and sickness absence and turnover, such that organizations with a high percentage of older workers benefited from work schedule practices, and organizations with high percentage of younger workers benefited from development practices.
\end{abstract}

Keywords: Individualized HRM Practices, organizational performance, employee turnover, sickness absence, older workers.

Running Head: Individualized HRM and Organizational Performance 
As organizations increasingly stress the importance among employees to be responsible for their own careers (Greenhaus, Callanan, \& Godshalk, 2010), a growing number of employees have begun to negotiate individual work arrangements with their employers (Rousseau, 2005). Moreover, this trend of individualization has occurred along with a decrease in collective agreements for employees (De Leede, Looise \& Van Riemsdijk, 2004; Glassner \& Keune, 2012). Accordingly, academic interest has begun to focus on how employees proactively shape their careers and negotiate individual agreements (Bal, De Jong, Jansen, \& Bakker, 2012; Grant \& Parker, 2009; Rousseau, 2005). Studies on idiosyncratic deals, or i-deals, have shown that individuals who proactively negotiate individual agreements become more highly motivated, committed and performing (e.g., Anand, Vidyarthi, Liden, \& Rousseau, 2010; Hornung, Glaser, \& Rousseau, 2008; Rosen, Slater, Chang \& Johnson, 2013). However, research from an organizational perspective on the increasing individualization of work is lacking (Taskin \& Devos, 2005). This is surprising, given the strong increase in interest on outcomes of individual employee negotiation. It is currently unknown whether this individualization of HRM actually improves organizational performance.

Studies on the effects of individualization on the employee level have shown that relationships with outcomes are inconsistent and differ greatly among studies (Bal et al., 2012; Hornung et al., 2008; Hornung, Rousseau, Glaser, Angerer, \& Weigl, 2010). We argue that individualization is primarily beneficial when it is in line with other aspects in the organization (De Leede et al., 2007; Delery \& Doty, 1996), and in particular the number of older workers in an organization is crucial in determining the effects of individualization of HRM (Bal et al., 2012; Bal et al., 2013; Kooij et al., 2013). Since workforces are aging throughout the world (Wang \& Shultz, 2010), the need for retention of older workers in organizations has become a prominent area of research (Wang \& Shultz, 2010). At the same 
time, it has become more difficult to retain older workers (as well as their expertise and knowledge) because many older workers leave the workforce early (Wang \& Shultz, 2010). Due to the increasing age diversity in the workplace (Schlick et al., 2013), it is imperative that organizations implement practices that allow older workers to maintain their productivity, as performance may be decreasing after the age of 40-45 (Ng \& Feldman, 2008). Individualized HRM may facilitate younger and older workers to negotiate individualized agreements to increase or maintain their performance, and hence contribute to overall performance of the organization.

The objective of this study is to test the effectiveness of individualization on organizational performance; specifically, whether the effectiveness of individualization depends on the age composition of the organization. First, we investigate whether the availability and actual use of individualized HRM contributes to organizational performance. Second, the study aims to determine the conditions under which individualization has the greatest effect on organizational performance by investigating the moderating role of employee age in the organization. Based on the notion that older workers have different workrelated needs from younger workers, we expected differences in the relationships of various types of individualized HRM with organizational performance (Bal et al., 2012; Kooij et al., 2013).

This study contributes to research on individualization of work arrangements by being the first to investigate the effects of individualization on organizational-level rather than on individual-level outcomes (Hornung et al., 2008). Demonstrating that individualization contributes to the bottom-line not only furthers our understanding of individualized HRM, but it also investigates the effects of individualization in a society where collective agreements are slowly disappearing (De Leede et al., 2004). Moreover, the study contributes by investigating the conditions under which individualization is most effective. We look at the role of the age 
composition within the organization, and through this we open up new pathways for research on HRM. Finally, this study contributes to previous research on individualization through the investigation of a large-scale employer sample (including numerous organizations in different sectors) and thereby obtaining a comprehensive perspective on how individualized HRM influences organizational outcomes.

\section{Theory and Hypotheses}

The individualization of HRM has become increasingly common in organizations as a result of globalization, the information economy, and the democratization of the workplace (Taskin \& Devos, 2005). Employees are becoming more proactive in looking for opportunities to negotiate individual agreements with their employers (Grant \& Parker, 2009; Rousseau, Ho, \& Greenberg, 2006), while at the same time organizations are also expecting employees to become more proactive. Consequently, organizations increasingly provide employees with the individual opportunity to negotiate agreements about work arrangements. This differs from the traditional HRM approach, which is fundamentally based on equal treatment of all employees (Boxall \& Macky, 2009).

Research on effectiveness of human resource management (HRM) has focused primarily on the universalistic outcomes of high-performance HRM (Boxall \& Macky, 2009; Delery \& Doty, 1996), based on the assumption that HR practices have a universal effect on motivation and performance among all employees. This high-performance approach to HRM (e.g., Kehoe \& Wright, 2013) postulates that the more HRM is available in organizations, the higher firm performance will be. However, as Kaufman and Miller (2011) argued, this statement may be oversimplified. A contingency approach, which stresses the idea that HRM should be in line with the goals and the context of the organization (Delery \& Doty, 1996), may be necessary to understand the consequences of HRM. 
Individualized HRM goes beyond the contingency approach, by introducing a perspective based on the individual employee rather than the goals of the organization. While there is some research that shows that HRM should be aligned with the needs of employees (Bal et al., 2013; Kinnie, Hutchinson, Purcell, Rayton, \& Swart, 2005), there is no research that specifically focuses on the individual employee as the basis of HRM. The trend of individualization in organizations is a reflection of a broader societal trend of individualism (Oyserman, Coon, \& Kemmelmeier, 2002), indicated by the decline of collective social structures, and a stronger focus on the individual's responsibility for their own welfare and wellbeing. This has also affected the traditional system of collective bargaining (De Leede et al., 2004), with collective agreements as the basis for HRM practices slowly decreasing (Glassner \& Keune, 2012). In response to the decrease in employee protective collective agreements and a decentralization of bargaining to the individual employee level (De Leede et al., 2004), individualization has grown significantly as the basis for organizational strategic HRM, and thus individualized HRM has become more common in organizations. Consequently, organizations increasingly allow their managers to make individual agreements with the employees.

We define individualized HRM as an HR system where managers have the opportunity and actually use the opportunity to individually negotiate agreements about work arrangements with individual employees. In the current study, we approach individualized HRM as HR programs that are implemented as HR practices in an organization (Arthur \& Boyles, 2007). Hence, instead of a standardized approach based on equal treatment of employees, individualized HRM refers to the extent that managers and employees are empowered to negotiate arrangements that fit the specific needs and preferences of the individual employee (De Leede et al., 2004). Individualized HRM includes customized work 
arrangements or i-deals on issues such as working hours, rewards, training and career development (Rousseau, 2005; Hornung, Rousseau, \& Glaser, 2009).

Individualized HRM is not a new phenomenon in organizations (Rousseau, 2005), but individual deals have traditionally been negotiated under the radar, and thus outside of the organization's control and agreement. This may have contributed to perceptions of unfairness and cronyism (Brick, Palmon, \& Wald, 2006). Individualized HRM, however, concerns the organization's explicit approval of individual negotiations of employees with managers as a strategic means of achieving the goals of the organization (De Leede et al., 2004; Rousseau, 2005). Moreover, individualized HR should be in line with existing law and collective agreements which every organization has to adhere to.

Individualized HRM is similar, yet different, from i-deals, or idiosyncratic deals employees negotiate with their employers (Rousseau, 2005; Rousseau et al., 2006). I-deals are negotiations of individual employees with their organizations, and primarily initiated by the employee, while individualized HRM refers to a formalized approach by the organization to customize work arrangements. Individualized HRM thus makes individualization of work arrangements available to all employees, contributing to higher fairness (Greenberg, Roberge, Ho \& Rousseau, 2004).

We make a further distinction between the availability and actual use of individualized HRM. This is in line with the strategic HR literature, which distinguishes between HR practices that are available to line managers from the actual use of these practices (e.g., Arthur \& Boyles, 2007). We apply the same logic to individualized HRM: in the former case, organizations provide leeway for line managers to negotiate if and when employees ask for individual agreements (i.e., availability), whereas in the latter, line managers actually use this leeway to negotiate agreements with employees. Both availability and actual use may influence positive outcomes, although via distinct theoretical processes. 
First, the effects of availability of individualized HRM on organizational performance can be explained with signaling theory. Signaling theory (Casper \& Harris, 2008) proposes that since employees have incomplete information about the organization's intentions, they use signals from the organization to draw conclusions about an organization's intentions and actions. As such, the availability of individualized HRM functions as 'signals' of the organization's benevolent intentions toward employees (e.g., Takeuchi, Chen, \& Lepak, 2009). Social exchange theory (Blau, 1964) proposes in turn that employees will reciprocate these good intentions through increased commitment to the organization, and consequently higher performance and retention (Bal et al., 2013).

Second, the effects of the use of individualized HRM on organizational performance can be explained using the norm of reciprocity, which is also related to social exchange theory (Blau, 1964; Gouldner, 1960). According to social exchange theory, when an employee and an employer commit to each other in an exchange relationship, reciprocal obligations between the two parties drive their behavior. Individualized HRM serves as a basis for reciprocity between the employee and the organization, because the mutual obligations that have been agreed upon strengthen the employment relationship. More specifically, the organization negotiates individual deals with employees, and in return, employees become more attached to the organization (Hornung et al., 2008; Ng and Feldman, 2010) and contribute to a higher degree (Hornung et al., 2008). Hence, the use of individualized HRM in organizations is expected to be positively related to organizational performance. In this study we adopt a broad conceptualization of organizational performance which includes three distinct performance indicators: operational performance growth, sickness absence and voluntary employee turnover (Peretz \& Fried, 2012).

Individualized HRM practices may entail various types of agreements, but previous research has shown that the most common agreements are aimed at development (i.e., training 
and career development), flexibility in work schedules (i.e., working hours), and financial agreements (i.e., salary; De Leede et al., 2004, 2007; Rosen et al., 2013). Hence, in this study we differentiate among development, work schedules and pay arrangements practices, and we expect that these three practices will be differentially related to types of organizational performance. Development practices motivate and reward high performance (Hornung et al., 2008, 2011). Through development, including training and special opportunities for skill development, employees may enhance their own performance. In line with the AMO-model (Appelbaum et al., 2000), development provides employees with the abilities and motivation to perform. Hence, development practices motivate employees to perform, but also to stay within the organization. In line with the norm of reciprocity, when employees receive development they become more committed to the organization, and hence, more likely to stay. Thus, we expect that development practices are related to organizational performance as well as turnover.

Individualized work schedule practices will enhance employee motivation in line with the work adjustment model; through negotiation of personalized work schedules, greater correspondence is achieved between the employees' abilities and the requirements of the job (Baltes, Briggs, Huff, Wright, \& Neuman, 1999). When job requirements are adapted to individual abilities, employees are better able to fulfill their job role; for example, flexible work schedule practices allow employees to arrange their work hours to better align with their personal situation. Consequently, employees are better able to do their job without dropping out (e.g., through burnout), and hence work schedule practices are expected to contribute to lower employee sickness absence. Previous research has shown that flexible work arrangements indeed tend to reduce absenteeism in organizations (De Menezes \& Kelliher, 2011). 
Finally, individualized pay practices reflect the economic conditions of a job (Rosen et al., 2013), and signal to employees that the current organization values and wants to retain them. Pay practices also increase contract unreplicability (Rosen et al., 2013), since the financial benefits of a job can be easily compared with other jobs, and hence decrease the likelihood that employees will turnover. Thus, financial practices are expected to be related to lower employee turnover, since employers are likely to offer special compensation packages or incentives to their valued employees in order to retain them. In sum, both availability and use of individualized HRM in organization are expected to be positively related to types of organizational performance. To summarize the arguments above, our first three hypotheses are:

Hypothesis 1: Availability and use of individualized development practices are positively related to (a) performance growth, and negatively related to $(b)$ employee turnover.

Hypothesis 2: Availability and use of individualized work schedule practices are negatively related to sickness absence.

Hypothesis 3: Availability and use of individualized pay practices are negatively related to employee turnover.

\section{Employee Age and Effectiveness of Individualized HRM}

We argue that the effectiveness of individualized HRM is dependent upon the context, and in particular the composition of the employee population (Bal et al., 2013; Kooij et al., 2013). A basic notion of social exchange theory is that the utility employees attach to resources determines the likelihood of the expected effects. Accordingly, previous studies have shown that individualized agreements are more likely to produce positive outcomes when they are in line with employee needs (Anand et al., 2010; Bal et al., 2012). We argue that the relationship between the use of individualized HRM and organizational performance will depend upon the extent to which it fits the needs of older workers. We expect this to be the case for use of individualized HRM rather than availability, since the utility of 
individualized HRM is manifested particularly when workers have actually negotiated agreements with their organization (Rousseau, 2005).

Lifespan psychology has shown that aging is associated with changes in needs and preferences (Baltes \& Baltes, 1990; Kooij et al., 2011). Socioemotional selectivity theory (Carstensen, 2006; Carstensen \& Mikels, 2005) has been used extensively in understanding how older people differ from younger people in motivation and behavior, as well as in explaining the impact of age on work behaviors (Kooij et al., 2011). Socio-emotional selectivity theory states that in young adulthood, time is perceived as expansive (Carstensen, 2006). Young people have an open future time perspective and prepare for a long and unknown future and therefore primarily focus on growth and knowledge-related goals. Older people, however, increasingly experience time as running out. For them, the experience of approaching the end their careers and life causes a shift towards present-related emotional goals over knowledge goals, and a focus on emotional well-being (Carstensen \& Mikels, 2005). Because younger people have broader time horizons, they prepare for a long and unknown future by learning and seeking growth opportunities. Older people, however, increasingly experience time as running out, and hence perceive less future in their organization, causing them to prioritize present-related goals over future-oriented goals.

Moreover, the lifespan Selection, Optimization, and Compensation (SOC-) Model of Baltes (1997, Baltes \& Baltes, 1990) proposes that throughout life, people experience gains and losses in physical and mental capabilities, and they are in general focused on maximizing the benefits of these changes while minimizing their losses (Kanfer \& Ackerman, 2004). To minimize losses in outcomes due to the losses in abilities aging people experience, they select fewer goals and refrain from learning so that they do not have to spread their diminished resources over too many goals and can thus remain healthy and productive contributors in the organization (Baltes \& Baltes, 1990; Baltes, 1997). Hence, the SOC-model also predicts that 
while younger workers have higher growth needs, there is a decline in these needs over the lifespan. Older workers cope with age-related losses, such as declines in health, physical capabilities, and memory, and become more focused on maintaining what they have and minimizing the effects of the losses they experience.

In sum, these lifespan theories suggest that while younger workers are generally more focused on building their careers, learning, and growth, older workers employ strategies to cope with age-related losses. Hence, the utility of different types of individualized HR practices will accordingly vary depending on the age of the workers. Individualized pay arrangements and development will be more important for younger workers, because these facilitate career growth and learning. Individualized work schedules, however, will be more important for older workers because they facilitate a more flexible way of coping with agerelated losses and the demands at work. Thus, the possibility for older workers to negotiate an individualized work schedule with their employer enables them to remain productive, and prevents them from higher sickness absence. We expect therefore that in organizations with many older workers, use of individualized work schedules will be more strongly related to performance and sickness absence.

In contrast, we expect individualized development and pay practices to be more important among younger workers (Ebner, Freund, \& Baltes, 2006). Younger workers primarily tend to seek to optimize resources or maximize economic gains and career development, enhancing their status and advancement within their organization and career (Maurer, Weiss, \& Barbeite, 2003). Recent meta-analytic work has indeed shown that growth and extrinsic work motives are more important for younger workers than for older workers (Kooij, De Lange, Jansen, Kanfer, \& Dikkers, 2011). Extending this logic, we propose that the use of development and pay agreements are more important for younger workers, and hence in organizations with many younger workers, individualized development and pay 
practices will be more strongly related to performance growth and turnover. Based on the above, we propose the following hypotheses:

Hypothesis 4: employee age moderates the relationship between use of individualized development practices and (a) performance growth and $(b)$ employee turnover, such that the relation is weaker for organizations with a high percentage of older workers.

Hypothesis 5: employee age moderates the relationship between use of individualized work schedule practices and sickness absence, such that the relation is stronger for organizations with a high percentage of older workers.

Hypothesis 6: employee age moderates the relationship between use of individualized pay practices and employee turnover, such that the relation is weaker for organizations with a high percentage of older workers.

\section{Methods}

\section{Sample and Procedure}

The Netherlands Employers Work Survey (NEWS; Oeij, De Vroome, Kraan, Van den Bossche, \& Goudswaard, 2011) is a study of employment arrangements in organizations in the Netherlands and was carried out in 2010. NEWS is a representative survey among more than 5,000 for-profit as well as non-profit organizations counting two or more employees. Because the current study was part of a larger study on employer policies and conditions, the survey included various other questions. Therefore, the likelihood of respondents being aware of the aims of the current study would be minimal. The sample selected was a stratified sample based on sector and organization size. Organizations were approached by mail and telephone to participate in the research at the establishment-level. This means that for larger organizations with multiple (regional) establishments, respondents were approached at a lower hierarchical level where they could more accurately judge the actual use of individualized HRM practices. The focus of the current study is thus on the establishmentlevel.

Respondents (company owners, management team members or HR-managers) were able to participate through filling out either a paper-and-pencil or a digital questionnaire. It was deemed appropriate to ask company owners or HR managers to act as organizational 
representatives and to fill out the survey, since they would be aware of the policies of their organization, as well as the extent to which individualized HRM practices would be actually used (Arthur \& Boyles, 2007). Moreover, on average the establishments consisted of 161 employees, because of which it is likely that HR-managers were able to accurately assess availability and use of HR practices. If they were unaware of the use of individual agreements in their organization, it would be likely that the existence of these individual agreements was in fact cronyism or favoritism, rather than organizationally approved individualized HRM (Rousseau et al., 2006). The initial response was from 5,518 establishments (37\% response rate). 3,317 (60\%) represented independent companies that were not part of a larger firm. 1,417 responses were based on establishments of Dutch companies or multinational companies (with a foreign owner), and 784 were based on separate head offices of Dutch or multinational companies. There is no indication that one particular organization was overrepresented in the dataset. After deleting participants with missing responses, we obtained a final response of 4,591 organizations ( $31 \%$ response rate). $38 \%$ of the respondents were director or owner, $36 \%$ were HR-managers, $14 \%$ establishment managers, and $12 \%$ had another function in the organization. $71 \%$ of the organizations were for-profit firms, $22 \%$ nonprofit, and 7\% had both for-profit and non-profit activities.

\section{Measures}

Individualized HR practices were measured in line with previous research on HRM as well as i-deals (e.g., Casper \& Harris, 2008; Hornung et al., 2008, 2009). Availability of individualized HRM was measured by asking respondents the extent to which in their organization different agreements could be made with individual employees. Responses could be provided on a 5-point scale ( $1=$ not available at all; $5=$ available to a great extent $)$. Availability was measured with one-item scales for development (development/education of employees), work schedules (working hours of employees), and pay arrangements (salary of 
employees). Use of individualized HRM was measured by asking respondents to indicate the extent to which in their organization supervisors actually negotiated individualized agreements with employees $(1=$ not at all; $5=$ to a very great extent $)$. Use of individualized HRM was measured with the same items as availability. One-item scales were used because of restrictions on survey length. Even though the reliability of one-item scales could not be assessed in this study, the scales have strong practical relevance to the participants, as individualized HRM was widely acknowledged to be an important topic (Bal et al., 2012). Organizational performance was conceptualized broadly as the effectiveness of the organization to perform, ensure employee well-being and retention. It was measured using three indicators. Performance growth $(\alpha=.72)$ was measured through three items referring to performance growth during the last two years. We chose performance growth because many organizations from various sectors took part in the study, and objective indicators such as sales rates, profits, or ROI are not applicable to every organization (such as non-profit organizations; Peretz \& Fried, 2012). Ratings of organizational performance growth have been estimated as valid and reliable indicators of organizational performance (Gong, Law, Chang, \& Xin, 2009; Ngo, Foley, \& Loi, 2009). The items were: "Over the last two years, the labor productivity in our organization has ...", "The quality of our products and/or services has...", and "the satisfaction of the customers of our organization has...". Answers could be provided on a 5-point scale ranging from $1=$ 'strongly decreased' to $5=$ 'strongly increased'. Sickness Absence was measured by asking respondents the percentage of sickness absence during the previous year (2009), excluding pregnancy leave. The mean percentage was $3.51 \%$ ( $\mathrm{SD}=3.67)$. Employee Turnover $(\mathrm{M}=5.06 \%, \mathrm{SD}=13.35)$ was measured by asking the number of contracts that were voluntarily ended by employees themselves during the last year. This number was divided by the total number of employees with a permanent contract in the organization to obtain the percentage of employee turnover. The moderator employee age was 
measured by indicating the percentage of employees older than 45 years in the organization $(\mathrm{M}=39.6 \%, \mathrm{SD}=24.78) .45$ years is generally considered to be the age after which employees are regarded as older workers, and from that age experience increasing problems with their (physical) abilities to do their jobs (Kooij, De Lange, Jansen, \& Dikkers, 2008; Ng \& Feldman, 2008). While there is no strong theoretical cut-off point for distinguishing younger and older workers, age causes gradual changes in how people experience their work (Kooij et al., 2011). In the meta-analysis of $\mathrm{Ng}$ and Feldman (2008) on the relationship between age and job performance, it was estimated that the relationship of age with job performance was positive until the age of 40, after which it became negative. Moreover, in the review of Kooij and colleagues (2008), it was shown that the effect of chronological age on work motivation changed after the age of 40-45. Hence, there is a general consensus that after the age of 40-45, people experience age-related changes, and perceive changes in their motivation in their work as a result of aging. Moreover, research shows that after the age of 40-45, people have higher risk for work-related diseases (Alavinia, Van den Berg, Van Duivenbooden, Elders, \& Burdorf, 2009).

\section{Control Variables}

In the analyses, we controlled for a range of factors that could possibly influence the outcome variables (see also Gong et al., 2009; Ngo et al., 2009). Education was measured (using dummy coding) by the percentage of employees who had lower education ( $\mathrm{M}=30.84 \%$, $\mathrm{SD}=31.09 \%)$, vocational education $(\mathrm{M}=40.46 \%, \mathrm{SD}=28.54 \%)$, and higher education $(\mathrm{M}=28.73 \%, \mathrm{SD}=31.42 \%)$. Gender was measured as the percentage of male employees $(\mathrm{M}=58.38 \%, \mathrm{SD}=30.67 \%)$. Moreover, we controlled for the percentage of employees with a temporary contract $(\mathrm{M}=10.49 \%, \mathrm{SD}=14.78 \%)$ and the percentage of employees working parttime $(\mathrm{M}=37.89 \%, \mathrm{SD}=31.74 \%)$ to rule out alternative explanations, such as that turnover rates are influenced by the percentage of employees with a temporary contract. Furthermore, we 
controlled for sector (using dummy coding; Industry/Agricultural: 26\%; Service: 47\%;

Government: 4\%; Education: 9\%; Health care: $8 \%$; other sectors: 6\%). Finally, we controlled for organization size, since larger firms may have more resources and market power (Gong et al., 2009). Organization size $(M=162, S D=546.98)$ was measured by the number of employees working for the organization. For multinational organizations, respondents indicated the number of employees within the Netherlands.

\section{Analysis}

Because some of the variables were non-normally distributed, we applied log transformation to the variables education, gender, percentage of temporary employment, percentage of part-time workers, organization size, percentage of employees above 45 years, sickness absence and employee turnover (Finch, West, \& MacKinnon, 1997). The hypotheses were tested using moderated hierarchical regression analyses. Independent variables were standardized before interactions were calculated (Aiken \& West, 1991). In the first step, control variables were added to the model (not shown in table). For categorical variables, we created dummy variables and included these in the analyses. For education, percentage of employees with lower education was the reference group, and for sector we used industry/agricultural as reference group. Subsequently, main effects were added in the second step and in the final step the interactions. We included non-hypothesized main effects (e.g., of work schedule and financial practices on performance growth), as well as non-hypothesized interactions to rule out alternative explanations. Significant interactions were plotted with slopes for one standard deviation below and above the mean of the moderator (Aiken \& West, 1991). Table 1 shows the correlations among the variables.

Insert Table 1 about here

\section{RESULTS}


H1 predicted that availability and use of individualized development practices would be positively related to performance growth and negatively related to employee turnover. Table 2 shows the results of the hierarchical regression analyses. Both availability $(\beta=.079$, $p<.001)$ and use $(\beta=.058, p<.01)$ of individualized development practices were positively related to performance growth. Hence H1a was fully supported. Both availability and use of individualized development practices for employees are related to stronger performance growth of the organization. However, availability of individualized development practices was not related to employee turnover $(\beta=.003, n s)$, and use of development practices was also unrelated to employee turnover $(\beta=-.031, n s)$. Hence, H1b was rejected.

$\mathrm{H} 2$ predicted that availability and use of individualized work schedule practices would be negatively related to sickness-related absence. Availability $(\beta=-.066, p<.001)$ but not use $(\beta=-.018, n s)$ of individualized work schedule practices was negatively related to sickness absence, indicating lower sickness absence in organizations where individualized work schedules are available. Hence $\mathrm{H} 2$ was partially supported. We also found a non-hypothesized relationship between use of work schedule practices with performance growth $(\beta=.067$, $p<.01$ ), indicating that organizations with more employees using individualized work schedules obtained higher performance growth.

$\mathrm{H} 3$ predicted that availability and use of individualized financial practices would be negatively related to employee turnover. This hypothesis was partially supported; availability ( $\beta=-.045, p<.05)$ but not use $(\beta=.041, n s)$ was related to employee turnover.

Insert Table 2 about here

$\mathrm{H} 4$ predicted that employee age would moderate the relationship between use of individualized development practices and performance growth and employee turnover. Table 2 also shows the results of the moderation analyses. H4 was rejected; the interaction was not significantly related to performance growth $(\beta=-.019, n s)$ or to turnover $(\beta=.021, n s)$. Age, 
however, did moderate the relation between use of development practices and sickness absence $(\beta=.04, p<.01)$. Figure 1 shows the interaction between employee age and individualized development practices. The relation was non-significant for organizations with a low percentage of older workers $(\mathrm{B}=-.04, n s)$, while the relation was positive for organizations with high percentages of older workers $(\mathrm{B}=.11, p<.05)$. This indicates that the use of individualized development practices increases sickness absence in organizations with many older workers, while sickness absence is not affected among organizations with many younger workers using individualized development practices.

H5 predicted that employee age would moderate the relationship between the use of individualized work schedules and sickness absence. Age indeed moderated this relationship $(\beta=-.073, p<.001)$. Figure 2 shows the interaction pattern. In line with the hypothesis, the relationship was negative for organizations with a high percentage of older workers $(B=-.17$, $p<.001)$ while it was non-significant for organizations with few older workers $(\mathrm{B}=-.03, n s)$. H5 is therefore supported. We also found that the interaction between age and use of individualized work schedules in relation to employee turnover was significant $(\beta=-.047$, $p<.01)$. The interaction pattern is shown in Figure 3. The relation was non-significant for organizations with many older workers $(\mathrm{B}=-.06, n s)$, and the relation was positive for organizations with many younger workers $(B=.20, p<.05)$. Hence, turnover increased when organizations with many younger workers used many individualized work schedule practices.

Finally, H6 predicted that employee age would moderate the relationship between use of individualized pay practices and employee turnover. The interaction was significant $(\beta=.054, p<.01)$. Figure 4 shows the interaction. For organizations with low percentage of older workers, the relation was not significant $(\mathrm{B}=-.05, n s)$, while the relation was positive for organizations with many older workers $(\mathrm{B}=.28, p<.01)$. Thus, $\mathrm{H} 6$ was rejected; the relation 
was not stronger for organizations with many younger workers but positive for organizations with many older workers.

We also tested whether the relationships were stable if we increased the age to 55+. We ran all of the analyses using the percentage of workers above 55, and this produced the same results for the interaction hypotheses, as we obtained while using the percentage of workers above 45 .

Insert Figures 1-4 about here

\section{DISCUSSION}

This study investigated whether the availability and use of individualized HRM practices in organizations contributes to organizational performance, as well as whether these relations are moderated by employee age. Results from a large-scale employer survey among almost 4,600 organizations in the Netherlands demonstrated that, depending on the type of performance indicator, individualized HRM indeed contributes to higher organizational performance, supporting our main hypothesis of the study. Availability and use of individualized development HRM positively related to performance growth, and use of workschedule HRM also related positively to performance growth. Moreover, sickness absence is lower in organizations that have individualized work schedules available, while employee turnover is lower in organizations that have individualized pay practices available.

These findings largely support the predictions of signaling theory in the context of individualized HRM (Casper \& Harris, 2008), such that availability of individualization can act as an indicator for employees that the organization values them as members and hence positively relate to their contributions to the organization. When individualized development practices are available, employees put more effort into their jobs, and organizational performance will grow. Moreover, availability of individualized work schedules was related 
to lower sickness absence, while availability of individualized pay practices related to lower employee turnover

Moreover, the social exchange perspective on individualized HRM is also supported; use of individualized HRM was positively related to organizational performance. In line with our hypotheses, we found that use of individualized development practices are important for productivity because development enhances employees' skills to do the job and hence are better able to perform (Appelbaum et al., 2000; Hornung et al., 2009). Moreover, we also found positive relationships between the use of individualized work schedules and performance growth. This indicates that a more personalized working schedule is not only related to lower sickness absence and thus benefits employees' health, but can also contribute to higher performance. This provides some additional evidence for the question of whether flexible work arrangements actually lead to organizational performance (De Menezes \& Kelliher, 2011). The current study results suggest this may be the case, especially when managers use the opportunity to individually negotiate flexible work arrangements with employees.

\section{Employee Age and Effectiveness of Individualized HRM}

We have argued that the relationships between individualized HRM and performance outcomes differ among organizations with primarily younger vs. older workers. Lifespan theory (Baltes et al., 1999) suggests that the needs of younger workers are different from those of older workers, with younger workers primarily being motivated by growth and learning, while older workers are more highly motivated when they have the opportunity to flexibly arrange their work and non-work obligations.

However, we did not find stronger relationships in organizations with many younger workers when they used individualized development and pay arrangements. We found that use of development was related to higher sickness absence among organizations with many 
older workers. It may be that in organizations that put a lot of pressure on employee development, the older workers have more problems in coping with needs to rapidly adjust to new procedures and technology, which then manifests through higher sickness absence. Therefore, the claim that individualized development enhances performance (e.g., Anand et al., 2010) must be qualified, because development also means an investment of time and energy by the employee and may therefore be associated with higher absence for those employees who suffer physical losses, such as older workers (Bal et al., 2012). Moreover, individualized development may be costly for organizations, and hence it is important for organization to calculate the costs and benefits of individualized HRM.

The use of individualized pay was found to relate to higher turnover in organizations with many older workers, while it made no differences in organizations with many younger workers. Drawing from the notion that financial inducements are more likely to be negotiated by star performers (Rousseau, 2005), it may be that especially in organizations with many older workers, older workers are the star performers who can more easily find new jobs. Moreover, the absence of a relationship between individualized pay and performance growth also indicates that the role of reciprocity in the negotiation of financial deals does not have to be targeted at higher performance, but to other outcomes such as retention (Rousseau et al., 2006). However, individualized pay can also exist because of cronyism. This 'dark side' of individualized HRM can for instance found in research that showed existence of cronyism in the excess compensation of higher managers (Brick et al., 2006).

We found that individualized work schedules may be particularly effective in organizations with many older workers, because of its association with sickness absence, while in organizations with many younger workers, turnover was higher when individualized work schedules were used. Availability and use of individualized work schedules signal to employees that they have the opportunity to diminish workload, which is especially relevant 
for older workers who are facing difficulties with coping with their losses while retaining energy and motivation at work (Kanfer \& Ackerman, 2004). For younger workers, however, this may also be a signal that full investment in work is less important, and hence they might look for organizations where they can invest fully into their work and career. As a consequence, turnover increases for these organizations.

\section{Theoretical and Research Implications}

This study has several implications for theory and future research. The study shows that individualized HRM relates to higher organizational performance. This is important, since an increasing number of organizations have introduced individual negotiations with employees about their work arrangements (Bal et al., 2012). However, the relationships are not straightforward; the extent to which individualized HRM practices relate to higher performance depends upon both the type of HRM practice and the type of performance indicator. Hence, when taking the effects of individualized HRM on outcomes into account, a contingency approach is necessary. This study, therefore, contributes to the debate in the HRliterature on the value of high performance HR systems in relation to a contingency approach to HRM (e.g., Kaufman \& Miller, 2011; Purcell, 1999). This debate concerns the question whether more HRM always leads to higher organizational performance. This notion is challenged in the current study that clearly shows that a contingency approach is necessary to explain the relationship between HR-interventions, such as individualized HRM, and organizational performance. That is, organizational performance can be enhanced only when the type of individualized HRM fits the needs of workers. For instance, we found that availability of individualized development practices is important for performance growth, availability of individualized work schedules for sickness absence, and individualized pay arrangements is important for retention of employees. 
Moreover, in line with research on HRM (Arthur \& Boyles, 2007) it is also important to distinguish between the leeway managers have in negotiating individualized agreements with employees, and the actual use of individualized HRM in organizations by the managers. The former may be an indication for employees that they can, when necessary and needed, negotiate individual agreements. moreover, the latter provides an answer to the question whether the use of individualized HRM actually leads to higher performance, and bring about what they have been introduced for in organizations (Rousseau, 2005). As the current study has shown, the effects may be different. Especially availability is important for each employee, while the effectiveness of use of individualized HRM may be dependent on the composition of the workforce in organization.

Furthermore, the present study demonstrates that when theorizing about the effects of individualization in organizations it is important to take employee age into account (Bal et al., 2012; Kooij et al., 2013). A challenge for future research is to investigate the age-related changes that explain why older workers react differently from younger workers (Kooij et al., 2008). It has been proposed that older workers differ from each other, and that changes that people experience due to the aging process, develop differently for each individual. Hence, it is important to ascertain these underlying changes, such as declines in psychological perceptions of future time perspective (Bal, Jansen, Van der Velde, De Lange, \& Rousseau, 2010).

Another avenue for future research is to ascertain which groups of employees are more likely to prefer individualized agreements and proactively start negotiating those arrangements (Hornung et al., 2010). It has been suggested that individualized pay arrangements are only negotiated by star performers, while individualized work schedules are negotiated by low performers (Rousseau, 2005). Hence, the relationships between negotiated deals with outcomes may be also moderated by employee status. This is important in relation 
to the general decrease in collective agreements and representation in contemporary society (Glassner \& Keune, 2012). While trade unions may have less control over the work arrangements employees negotiate with their employers, organizations are also given the opportunity to create inequality and unfairness in how employees are treated (Greenberg et al., 2004). Thus, individualization comes with the risk of potential inequality among employees, and one of the implications of this study is that HRM models should factor in these changing social circumstances.

\section{Limitations and Suggestions for Future Research}

Since the present study was cross-sectional, one limitation is that we could not ascertain causality. Theoretically, it could be that high performing organizations may start to offer and use more individual deals, and especially when it concerns financial and developmental agreements, since these types of individualized HRM may be costly for organizations. However, previous research has shown that individualization of HRM is primarily a consequence of societal changes, rather than performance of organizations (De Leede et al., 2004, 2007). Moreover, the study was based on self-reports of organizational representatives. We were not able to have objective performance measures, because existing measures (such as profits or ROI) were not applicable to all of the organizations in the study, since we included both profit and nonprofit organizations. Therefore, we deemed it appropriate to use self-report measures of performance. Moreover, since the current study was part of a larger study, and several other scales were included in the survey, it was unlikely that participants were aware of the purposes of the current study. Moreover, due to this study being part of a larger study, short scales were used to measure our instruments. Even though these were based on previous research (Hornung et al., 2008), and can be valid and reliable (Nagy, 2002), future research should further ascertain the validity of these measures. 
Finally, the effect sizes were not very strong. Individualized HRM and the interactions generally accounted each for about $1 \%$ of the variance in the outcomes. While this is not very high, we still deem it important in relation to the outcomes we studied: performance growth, sickness absence, and turnover. However, the results may have important implications for organizations: if $1 \%$ of the variance in performance, sickness absence or turnover can be explained through individualized HRM, this may have important and strong effects for organizations and HR-managers since it may reflect a substantial monetary outcome for the organization. It is therefore imperative that organizations are aware of the costs and benefits of taking an individual approach to HRM, but at the same time organizations should also realize the intrinsic value of an individual approach to HRM in itself for employees and organizations (Taskin \& Devos, 2005).

\section{Practical Implications}

The study shows that when organizations make individualized HRM available, it is associated with higher organizational performance, including stronger performance growth and lower sickness absence and turnover. Thus, even during the economic recession, performance could grow when organizations offer the opportunity to negotiate and actually use individualized HRM with their employees. Especially with regards to the high costs of absence and turnover (TNO, 2010), it has become imperative for organizations to keep their employees healthy and try to retain them.

However, individualization in organizations does not automatically lead to higher performance. Managers should therefore be aware of the effects that specific types of agreements may have. Based on this, managers can take an individual approach and ascertain the goal of a negotiated agreement for both employee and organization. For instance, when an organization aims to decrease sickness absence it may be best to negotiate individualized work schedules with employees, and a similar case could be made for the relationship 
between individualized development and performance, as well as individual financial agreements and retention. Moreover, it is necessary for organizations to train their line managers in negotiating individual agreements with employees, since traditionally managers are educated and used to equal treatment rather than individualized treatment. Hence, line managers need to be aware of the individual needs of employees, and yet ensure fair treatment of their subordinates compared to coworkers (Greenberg et al., 2004).

Finally, organizations should also be aware that individualized treatment may have a different utility depending on the age of an employee, and while younger workers tend to value economic and development inducements, older workers have higher needs for flexibility (Bal et al., 2010).

\section{Conclusion}

The current study investigated whether individualized HRM contributed to organizational performance in a sample of nearly 4,600 Dutch companies. The study shows that individualized HRM is differentially related to performance indicators, and that these relationships are moderated by employee age. We found that individualized development and pay arrangements were particularly important for organizations with many younger workers to maintain organizational performance, while individualized work schedules are important in enhancing organizational performance in organizations with many older workers. 


\section{REFERENCES}

Aiken, L.S. \& West, S.G. (1991). Multiple Regression: Testing and Interpreting Interactions. San Francisco, CA: Sage Publications.

Alavinia, S.M., Van Den Berg, T.I., Van Duivenbooden, C., Elders, L.A., \& Burdorf, A. (2009). Impact of work-related factors, lifestyle, and work ability on sickness absence among Dutch construction workers. Scandinavian Journal of Work, Environment \& Health, 35, 325-333.

Anand, S., Vidyarthi, P.R., Liden, R.C., \& Rousseau, D.M. (2010). Good citizens in poorquality relationships: idiosyncratic deals as a substitute for relationship quality. Academy of Management Journal, 53, 970-988.

Appelbaum, E., Bailey, T., Berg, P., \& Kalleberg, A. (2000). Manufacturing competitive advantage: The effects of high performance work systems on plant performance and company outcomes. Ithaca, NY: Cornell University Press.

Arthur, J.B. and Boyles, T. (2007). Validating the human resource system structure: a levelsbased strategic HRM approach. Human Resource Management Review, 17, 77-92.

Bal, P.M., De Jong, S.B., Jansen, P.G.W., \& Bakker, A.B. (2012). Motivating employees to work beyond retirement: a multi-level study of the role of I-deals and unit climate. Journal of Management Studies, 49, 306-331.

Bal, P.M., Jansen, P.G.W., Van der Velde, M.E.G., De Lange, A.H., \& Rousseau, D.M. (2010). The role of future time perspective in psychological contracts: a study among older workers. Journal of Vocational Behavior, 76, 474-486.

Bal, P.M., Kooij, D.T.A.M., \& De Jong, S.B. (2013). How do developmental and accommodative HRM enhance employee engagement and commitment? The role of psychological contract and SOC-strategies. Journal of Management Studies, 50, 545-572. 
Baltes, P.B. (1997). On the incomplete architecture of human ontogeny. Selection optimization and compensation as foundation. American Psychologist, 52, 366-380.

Baltes, P.B. \& Baltes, M.M. (1990). Psychological perspectives on successful aging:The model of selective optimization with compensation. In Baltes, P.B. \& Baltes, M.M. (Eds) Successful aging: Perspectives from the behavioural sciences. New York: Cambridge University Press, 1-34.

Baltes, B.B., Briggs, T.E., Huff, J.W., Wright, J.A., \& Neuman, G.A. (1999). Flexible and compressed workweek schedules: a meta-analysis of their effects on work-related criteria. Journal of Applied Psychology, 84, 496-513.

Blau, P. M. (1964). Exchange and Power in Social Life. New York: Wiley.

Boxall, P., \& Macky, K. (2009). Research and theory on high-performance work systems: progressing the high-involvement stream. Human Resource Management Journal, 19, 323.

Brick, I.E., Palmon, O. \& Wald, J.K. (2006). CEO compensation, director compensation, and firm performance: evidence of cronyism? Journal of Corporate Finance, 12, 403-423.

Carstensen, L.L. (2006). The influence of a sense of time on human development. Science, $312,1913-1915$.

Carstensen, L.L., \& Mikels, J.A. (2005). At the intersection of emotion and cognition: aging and the positivity effect. Current Directions in Psychological Science, 14, 117-121.

Casper, W.J. \& Harris, C.M. (2008). Work-life benefits and organizational attachment: selfinterest utility and signalling theory models. Journal of Vocational Behavior, 72, 95-109.

De Leede, J., Huiskamp, R., Oeij, P., Nauta, A., Goudswaard, A., \& Kwakkelstein, T. (2007). Negotiating individual employment relations, evidence from four Dutch organizations. Revue Interventions Économique, 35, 1-16. 
De Leede J., Looise, J.C. \& Van Riemsdijk, M. (2004). Collectivism versus individualism in Dutch employment relations. Human Resource Management Journal, 14, 25-39.

De Menezes, L.M., \& Kelliher, C. (2011). Flexible working and performance: a systematic review of the evidence for a business case. International Journal of Management Reviews, 13, 452-474.

Delery, J.E. \& Doty, D.H. (1996). Modes of theorizing in strategic human resource management: tests of universalistic contingency and configurational performance predictions. Academy of Management Journal, 39, 802-835.

Ebner, N.C., Freund, A.M. \& Baltes, P.B. (2006). Developmental changes in personal goal orientation from young to late adulthood: from striving for gains to maintenance and prevention of losses. Psychology and Aging, 21, 664-678.

Finch, J.F., West, S.G., \& MacKinnon, D.P. (1997). Effects of sample size and nonnormality on the estimation of mediated effects in latent variable models. Structural Equation Modeling: A Multidisciplinary Journal, 4, 87-107.

Glassner, V., \& Keune, M. (2012). The crisis and social policy: The role of collective agreements. International Labour Review, 151, 351-375.

Gong, Y., Law, K.S, Chang, S., \& Xin, K.R. (2009). Human resource management and firm performance: the differential role of managerial affective and continuance commitment. Journal of Applied Psychology, 94, 263-275.

Gouldner, A.W. (1960). The norm of reciprocity: A preliminary statement. American Sociological Review, 25, 161-178.

Greenhaus, J.H., Callanan, G.A., \& Godshalk, V.M. (2010). Career Management. Thousand Oaks, CA: Sage Publications, $4^{\text {th }}$ Edition.

Grant, A.M., \& Parker, S.K. (2009). Redesigning work design theories: the rise of relational and proactive perspectives. Academy of Management Annals, 3, 317-375. 
Hornung, S., Rousseau, D.M., Glaser, J., Angerer, P., \& Weigl, M. (2010). Beyond top-down and bottom-up work redesign: customizing job content through idiosyncratic deals. Journal of Organizational Behavior, 31, 187-215.

Hornung, S., Glaser, J., Rousseau, D.M., Angerer, P., \& Weigl, M. (2011). Employeeoriented leadership and quality of working life: mediating roles of idiosyncratic deals. Psychological Reports, 108, 59-74.

Hornung, S., Rousseau, D.M., \& Glaser, J. (2008). Creating flexible work arrangements through idiosyncratic deals. Journal of Applied Psychology, 93, 655-664.

Hornung, S., Rousseau, D.M., \& Glaser, J. (2009). Why supervisors make idiosyncratic deals: antecedents and outcomes of I-deals from a managerial perspective. Journal of Managerial Psychology, 24, 739-764.

Kanfer, R. \& Ackerman, P. L. (2004). Aging, adult development and work motivation. Academy of Management Review, 29, 440-458.

Kaufman, B.E., \& Miller, B.I. (2011). The firm's choice of HRM practices: economics meets strategic human resource management. Industrial and Labor Relations Review, 64, 526557.

Kehoe, R.R., \& Wright, P.M. (2013). The impact of high performance HR practices on employees' attitudes and behaviors. Journal of Management. 39, 366-391.

Kinnie, N., Hutchinson, S., Purcell, J., Rayton, B., \& Swart, J. (2005). Satisfaction with HR practices and commitment to the organisation: why one size does not fit all. Human Resource Management Journal, 15, 9-29.

Kooij, D., De Lange, A., Jansen, P., \& Dikkers, J. (2008). Older workers' motivation to continue to work: five meanings of age. Journal of Managerial Psychology, 23, 364-394. 
Kooij, D., De Lange, A.H., Jansen, P.G.W., Kanfer, R., \& Dikkers, J. (2011). Age and workrelated motives: results of a meta-analysis. Journal of Organizational Behavior, 32, 197225.

Kooij, D.T.A.M., Guest, D.E., Clinton, M., Knight, T., Jansen, P.G.W., \& Dikkers, J.S.E. (2013). How the impact of HR practices on employee well-being and performance changes with age. Human Resource Management Journal, 23, 18-35.

Maurer, T.J., Weiss, E.M., \& Barbeite, F.G. (2003). A model of involvement in work-related learning and development activity: the effects of individual, situational, motivational, and age variables. Journal of Applied Psychology, 88, 707-724.

Nagy, M.S. (2002). Using a single-item approach to measure facet job satisfaction. Journal of Occupational and Organizational Psychology, 75, 77-86.

Ng, T.W., \& Feldman, D.C. (2008). The relationship of age to ten dimensions of job performance. Journal of Applied Psychology, 93, 392-423.

Ng, T.W.H., \& Feldman, D.C. (2010). Idiosyncratic deals and organizational commitment. Journal of Vocational Behavior, 76, 419-427.

Ngo, H.Y., Foley, S. \& Loi, R. (2009). Family friend work practices, organizational climate, and firm performance: a study of multinational corporations in Hong Kong. Journal of Organizational Behavior, 30, 665-680.

Oeij, P.R.A., De Vroome, E.M.M., Kraan, K., Van den Bossche, S., \& Goudswaard,A. (2011). Werkgevers Enquete Arbeid (WEA) 2010; Methodologische Verantwoording. Hoofddorp, NL: TNO.

Oyserman, D., Coon, H.M., \& Kemmelmeier, M. (2002). Rethinking individualism and collectivism: evaluation of theoretical assumptions and meta-analyses. Psychological Bulletin, 128, 3-72. 
Peretz, H., \& Fried, Y. (2012). National cultures, performance appraisal practices, and organizational absenteeism and turnover: a study across 21 countries. Journal of Applied Psychology, 97, 448-459.

Purcell, J. (1999). Best practice and best fit: chimera or cul-de-sac? Human Resource Management Journal, 9, 26-41.

Rosen, C.C., Slater, D.J., Chang, C.H., \& Johnson, R.E. (2013). Let's make a deal: development and validation of the ex post I-deals scale. Journal of Management, 39, 709742.

Rousseau, D.M. (2005). I-Deals: Idiosyncratic Deals Employees Bargain for Themselves. New York: M.E. Sharpe.

Rousseau, D.M., Ho, V.T. \& Greenberg, J. (2006). I-deals: idiosyncratic deals in employment relationships. Academy of Management Review, 31, 977-994.

Rousseau, D.M., Hornung, S., \& Kim, T.G. (2009). Idiosyncratic deals: testing propositions on timing, content, and the employment relationship. Journal of Vocational Behavior, 74, $338-348$.

Schlick, C. M., Frieling, E., \& Wegge, J. (2013). Age-differentiated Work Systems. Berlin, DE: Springer.

Takeuchi, R., Chen, G., \& Lepak, D.P. (2009). Through the looking glass of a social system: cross-level effects of high-performance work systems on employees' attitudes. Personnel Psychology, 62, 1-29.

Taskin, L., \& Devos, V. (2005). Paradoxes from the individualization of human resource management: The case of telework. Journal of Business Ethics, 62 , 13-24.

TNO (2010). http://www.eurofound.europa.eu/ewco/studies/tn0911039s/nl0911039q.htm.

Website accessed at November 14, 2012. 
Wang, M., \& Shultz, K.S. (2010). Employee retirement: a review and recommendations for future investigation. Journal of Management, 36, 172-206.

Zacher, H., Jimmieson, N.L., \& Winter, G. (2012). Eldercare demands, mental health, and work performance: the moderating role of satisfaction with eldercare tasks. Journal of Occupational Health Psychology, 17, 52-64. 
Table 1: Correlations between variables in the study $(N=4591)$.

\begin{tabular}{|c|c|c|c|c|c|c|c|c|c|c|c|}
\hline & Variables & Mean & SD & 1 & 2 & 3 & 4 & 5 & 6 & 7 & 8 \\
\hline \multicolumn{12}{|c|}{ Education } \\
\hline 1 & - $\quad \%$ Vocational Education & 40.46 & 28.54 & -- & & & & & & & \\
\hline 2 & - $\quad \%$ Higher Education & 28.73 & 31.42 & $-.45 * *$ & -- & & & & & & \\
\hline 3 & Gender $(\%$ men $)$ & 58.38 & 30.67 & $-.06^{* *}$ & $-.19^{* *}$ & -- & & & & & \\
\hline 4 & $\%$ Temporary Employment & 10.49 & 14.78 & .02 & $-.04^{* *}$ & $-.12^{* *}$ & -- & & & & \\
\hline 5 & $\%$ Part time workers & 37.89 & 31.74 & $.05^{* *}$ & $.12^{* *}$ & $-.70^{* *}$ & $.20^{* *}$ & -- & & & \\
\hline \multicolumn{12}{|c|}{ Sector } \\
\hline 6 & Service & .46 & -- & $.09^{* *}$ & $-.04^{* *}$ & $.07^{* *}$ & $.16^{* *}$ & $-.07^{* *}$ & -- & & \\
\hline 7 & - Government & .04 & -- & .01 & $.05^{* *}$ & .02 & $-.07^{* *}$ & $-.03^{*}$ & $-.18^{* *}$ & -- & \\
\hline 8 & - Education & .09 & -- & $-.17^{* *}$ & $.37^{* *}$ & $-.20^{* *}$ & -.02 & $.19^{* *}$ & $-.28^{* *}$ & $-.06^{* *}$ & -- \\
\hline 9 & - $\quad$ Health care & .08 & -- & $.09^{* *}$ & $.06^{* *}$ & $-.42^{* *}$ & .00 & $.38^{* *}$ & $-.30^{* *}$ & $-.06^{* *}$ & $-.09^{* *}$ \\
\hline 10 & - $\quad$ Other sectors & .06 & -- & -.02 & .02 & $-.15^{* *}$ & $.04^{* *}$ & $.15^{* *}$ & $-.23^{* *}$ & $-.05^{* *}$ & $-.07^{* *}$ \\
\hline 11 & Organization size (no. employees) & 161.63 & 546.98 & -.02 & $.05^{* *}$ & $-.06^{* *}$ & $-.04^{*}$ & $.06^{* *}$ & $-.06^{* *}$ & $.08^{* *}$ & $.03^{*}$ \\
\hline \multicolumn{12}{|c|}{ Availability of Individualized HRM } \\
\hline 12 & - Development & 3.61 & .80 & .02 & $.14^{* *}$ & .023 & -.02 & -.03 & .02 & .02 & $.05^{* *}$ \\
\hline 13 & - Work Schedule & 3.23 & 1.02 & .01 & $.13^{* *}$ & $-.10^{* *}$ & $.06^{* *}$ & $.15^{* *}$ & $.08^{* *}$ & $.06^{* *}$ & $-.08^{* *}$ \\
\hline 14 & - $\quad$ Pay Arrangements & 2.83 & 1.09 & $.05^{* *}$ & -.01 & $.18^{* *}$ & .00 & $-.19^{* *}$ & $.17^{* *}$ & $-.12^{* *}$ & $-.18^{* *}$ \\
\hline \multicolumn{12}{|c|}{ Use of Individualized HRM } \\
\hline 15 & - Development & 3.26 & .88 & -.01 & $.17^{* *}$ & $-.03^{*}$ & .00 & .01 & .02 & $.04^{*}$ & $.07^{* *}$ \\
\hline 16 & - Work Schedule & 2.97 & 1.02 & .01 & $.07^{* *}$ & $-.09^{* *}$ & $.10^{* *}$ & $.13^{* *}$ & $.09^{* *}$ & .02 & $-.08^{* *}$ \\
\hline 17 & - $\quad$ Pay Arrangements & 2.60 & 1.07 & $.04^{*}$ & .01 & $.17^{* *}$ & .02 & $-.19^{* *}$ & $.16^{* *}$ & $-.09^{* *}$ & $-.17^{* *}$ \\
\hline 18 & $\%$ of Employees $>45$ years $($ Age $)$ & 39.64 & 24.78 & $-.07^{* *}$ & $.05^{* *}$ & -.00 & $-.21^{* *}$ & $.04^{* *}$ & $-.23^{* *}$ & $.11^{* *}$ & $.16^{* *}$ \\
\hline 19 & Performance Growth & 3.46 & .52 & .01 & $.11^{* *}$ & $-.10^{* *}$ & $.09^{* *}$ & $.06^{* *}$ & $.04^{* *}$ & -.01 & .02 \\
\hline 20 & Sickness Absence & 3.51 & 3.67 & $-.08^{* *}$ & $-.05^{* *}$ & $-.04^{*}$ & -.02 & $.04^{*}$ & $-.17^{* *}$ & $.07^{* *}$ & $.05^{* *}$ \\
\hline 21 & Employee Turnover & 5.06 & 13.35 & $.04^{* *}$ & $-.03^{*}$ & $-.07^{* *}$ & $.25^{* *}$ & $.09^{* *}$ & $.12^{* *}$ & $-.04^{* *}$ & $-.03^{*}$ \\
\hline
\end{tabular}

Note. $* p<.05, * * p<.01, * * * p<.001$. 
Individualized HRM and Organizational Performance 36

\begin{tabular}{|c|c|c|c|c|c|c|c|c|c|c|c|c|c|c|}
\hline & Variables & 9 & 10 & 11 & 12 & 13 & 14 & 15 & 16 & 17 & 18 & 19 & 20 & 21 \\
\hline \multicolumn{15}{|c|}{ Education } \\
\hline 1 & - $\quad \%$ Vocational Education & & & & & & & & & & & & & \\
\hline 2 & - $\quad \%$ Higher Education & & & & & & & & & & & & & \\
\hline 3 & Gender (\% men $)$ & & & & & & & & & & & & & \\
\hline 4 & $\%$ Temporary Employment & & & & & & & & & & & & & \\
\hline 5 & $\%$ Part time workers & & & & & & & & & & & & & \\
\hline \multicolumn{15}{|c|}{ Sector } \\
\hline 6 & - $\quad$ Service & & & & & & & & & & & & & \\
\hline 7 & - Government & & & & & & & & & & & & & \\
\hline 8 & - $\quad$ Education & & & & & & & & & & & & & \\
\hline 9 & - $\quad$ Health care & -- & & & & & & & & & & & & \\
\hline 10 & - $\quad$ Other sectors & $-.08 * *$ & -- & & & & & & & & & & & \\
\hline 11 & Organization size (no. employees) & $.14^{* *}$ & -.02 & -- & & & & & & & & & & \\
\hline \multicolumn{15}{|c|}{ Availability of Individualized HRM } \\
\hline 12 & - Development & $-.13^{* *}$ & $-.05^{* *}$ & $-.09^{* *}$ & -- & & & & & & & & & \\
\hline 13 & - Work Schedule & $.03^{*}$ & $.06^{* *}$ & .00 & $.28 * *$ & -- & & & & & & & & \\
\hline 14 & - $\quad$ Pay Arrangements & $-.13^{* *}$ & $-.05^{* *}$ & $-.09^{* *}$ & $.26 * *$ & $.38 * *$ & -- & & & & & & & \\
\hline \multicolumn{15}{|c|}{ Use of Individualized HRM } \\
\hline 15 & - Development & .03 & -.02 & $.03^{*}$ & $.61 * *$ & $.18 * *$ & $.14 * *$ & -- & & & & & & \\
\hline 16 & - Work Schedule & $.06^{* *}$ & $.06^{* *}$ & .02 & $.22 * *$ & $.65^{* *}$ & $.26^{* *}$ & $.35^{* *}$ & -- & & & & & \\
\hline 17 & - $\quad$ Pay Arrangements & $-.12^{* *}$ & $-.04^{* *}$ & $-.04^{* *}$ & $.22 * *$ & $.31 * *$ & $.72 * *$ & $.29 * *$ & $.40 * *$ & -- & & & & \\
\hline 18 & $\%$ of Employees $>45$ years (Age) & $.04^{* *}$ & $.03^{*}$ & $.11^{* *}$ & $-.05^{* *}$ & $-.04^{* *}$ & $-.15^{* *}$ & $-.03 *$ & $-.05^{* *}$ & $-.14^{* *}$ & -- & & & \\
\hline 19 & Performance Growth & $.06^{* *}$ & -.01 & .02 & $.15^{* *}$ & $.13^{* *}$ & $.06^{* *}$ & $.16^{* *}$ & $.15^{* *}$ & $.08^{* *}$ & $-.09^{* *}$ & -- & & \\
\hline 20 & Sickness Absence & $.11^{* *}$ & .01 & $.14^{* *}$ & -.01 & $-.11^{* *}$ & $-.16^{* *}$ & .01 & $-.09^{* *}$ & $-.12^{* *}$ & $.14^{* *}$ & -.02 & -- & \\
\hline 21 & Employee Turnover & -.01 & -.01 & $-.04^{* *}$ & $-.04^{* *}$ & .01 & -.01 & -.02 & $.05^{* *}$ & .02 & $-.17^{* *}$ & .01 & -.02 & -- \\
\hline
\end{tabular}


Table 2: Results of Moderated Regression Analyses

\begin{tabular}{|c|c|c|c|c|c|c|c|}
\hline \multirow{2}{*}{\multicolumn{2}{|c|}{ Variables }} & \multicolumn{2}{|c|}{ Performance Growth } & \multicolumn{2}{|c|}{ Sickness Absence } & \multicolumn{2}{|c|}{ Employee Turnover } \\
\hline & & $\beta$ & $\beta$ & $\beta$ & $\beta$ & $\beta$ & $\beta$ \\
\hline \multicolumn{8}{|c|}{ Control Variables } \\
\hline \multicolumn{8}{|c|}{ Education } \\
\hline$-\quad$ & Vocational Education & .020 & .021 & .004 & .006 & .029 & .028 \\
\hline$-\quad \mathrm{H}$ & Higher Education & $.093 * * *$ & $.093 * * *$ & .056 & .056 & .026 & .029 \\
\hline Gend & der (\% men $)$ & $-.065 * *$ & $-.066 * * *$ & .007 & .002 & -.009 & -.011 \\
\hline$\% \mathrm{Te}$ & emporary Employment & $.063 * * *$ & $.063 * * *$ & $.069 * * *$ & $.071 * * *$ & $.150 * * *$ & $.149 * * *$ \\
\hline$\% \mathrm{~Pa}$ & art time workers & -.014 & -.015 & .024 & .022 & $.058 * *$ & $.057 * *$ \\
\hline \multicolumn{8}{|c|}{ Sector } \\
\hline$-S$ & Service & .022 & .021 & $-.098 * * *$ & $-.096 * * *$ & $.068 * * *$ & $.070 * * *$ \\
\hline$-\quad($ & Government & -.018 & -.018 & .000 & .001 & -.030 & -.027 \\
\hline$-\quad \mathrm{E}$ & Education & .013 & .013 & -.022 & -.026 & .000 & .002 \\
\hline$-\quad \mathrm{H}$ & Health care & .036 & .035 & -.031 & -.032 & .033 & .037 \\
\hline$-\quad($ & Other sectors & -.023 & -.023 & -.002 & .000 & -.018 & -.014 \\
\hline $\begin{array}{l}\text { Orgal } \\
\text { empl }\end{array}$ & $\begin{array}{l}\text { anization size (no. } \\
\text { loyees) }\end{array}$ & -.014 & -.014 & $.487 * * *$ & $.481 * * *$ & $.354 * * *$ & $.351 * * *$ \\
\hline \multicolumn{8}{|c|}{ Availability of Individualized HRM } \\
\hline$-\quad I$ & Development & $.079 * * *$ & $.079 * * *$ & .005 & .005 & .003 & .004 \\
\hline$-\quad 1$ & Work Schedule & .017 & .017 & $-.066 * * *$ & $-.067 * * *$ & .016 & .012 \\
\hline$-\quad \mathrm{F}$ & Pay Arrangements & .017 & .017 & -.020 & -.018 & $-.045^{*}$ & -.044 \\
\hline \multicolumn{8}{|c|}{ Use of Individualized HRM } \\
\hline - I & Development & $.058 * *$ & $.059 * *$ & .022 & .019 & -.031 & -.031 \\
\hline$-\quad 1$ & Work Schedule & $.067 * *$ & $.068 * *$ & -.022 & -.018 & .015 & .019 \\
\hline$-\quad \mathrm{F}$ & Pay Arrangements & -.016 & -.017 & -.010 & -.009 & .041 & .038 \\
\hline $\begin{array}{l}\% \text { of } \\
\text { years }\end{array}$ & $\begin{array}{l}\text { f Employees > } 45 \\
\text { s (Age) }\end{array}$ & $-.081 * * *$ & $-.080 * * *$ & $.051 * * *$ & $.063 * * *$ & $-.110 * * *$ & $-.109 * * *$ \\
\hline \multicolumn{8}{|c|}{ Interaction Effects } \\
\hline$-\quad I$ & Development $*$ Age & & -.019 & & $.040 * *$ & & .021 \\
\hline$-\quad V$ & Work Schedule * Age & & -.004 & & $-.073 * * *$ & & $-.047 * *$ \\
\hline$-\quad \mathrm{F}$ & $\begin{array}{l}\text { Pay Arrangements * } \\
\text { Age }\end{array}$ & & -.006 & & -.010 & & $.054 * *$ \\
\hline $\mathrm{F}$ & & $12.14 * * *$ & $10.50 * * *$ & $108.18 * * *$ & $94.74 * * *$ & $48.49 * * *$ & $42.38 * * *$ \\
\hline$\Delta \mathrm{F}$ & & $10.01 * * * 1$ & .68 & $3.47 * * 1$ & $9.37 * * *$ & $12.27 * * * 1$ & $4.80 * *$ \\
\hline $\mathrm{R}^{2}$ & & .06 & .06 & .36 & .37 & .20 & .21 \\
\hline$\Delta \mathrm{R}^{2}$ & & .01 & .00 & .01 & .01 & .01 & .01 \\
\hline
\end{tabular}

Note: $* p<.05, * * p<.01, * * * p<.001 .{ }^{1}=$ comparison to model with control variables (not shown in

Table). 
Individualized HRM and Organizational Performance 38

\section{Figure Caption}

Figure 1: the interaction between use of development practices and percentage of older workers in relation to sickness absence.

Figure 2: the interaction between use of work schedule practices and percentage of older workers in relation to sickness absence.

Figure 3: the interaction between use of work schedule practices and percentage of older workers in relation to turnover.

Figure 4: the interaction between use of pay practices and percentage of older workers in relation to turnover. 

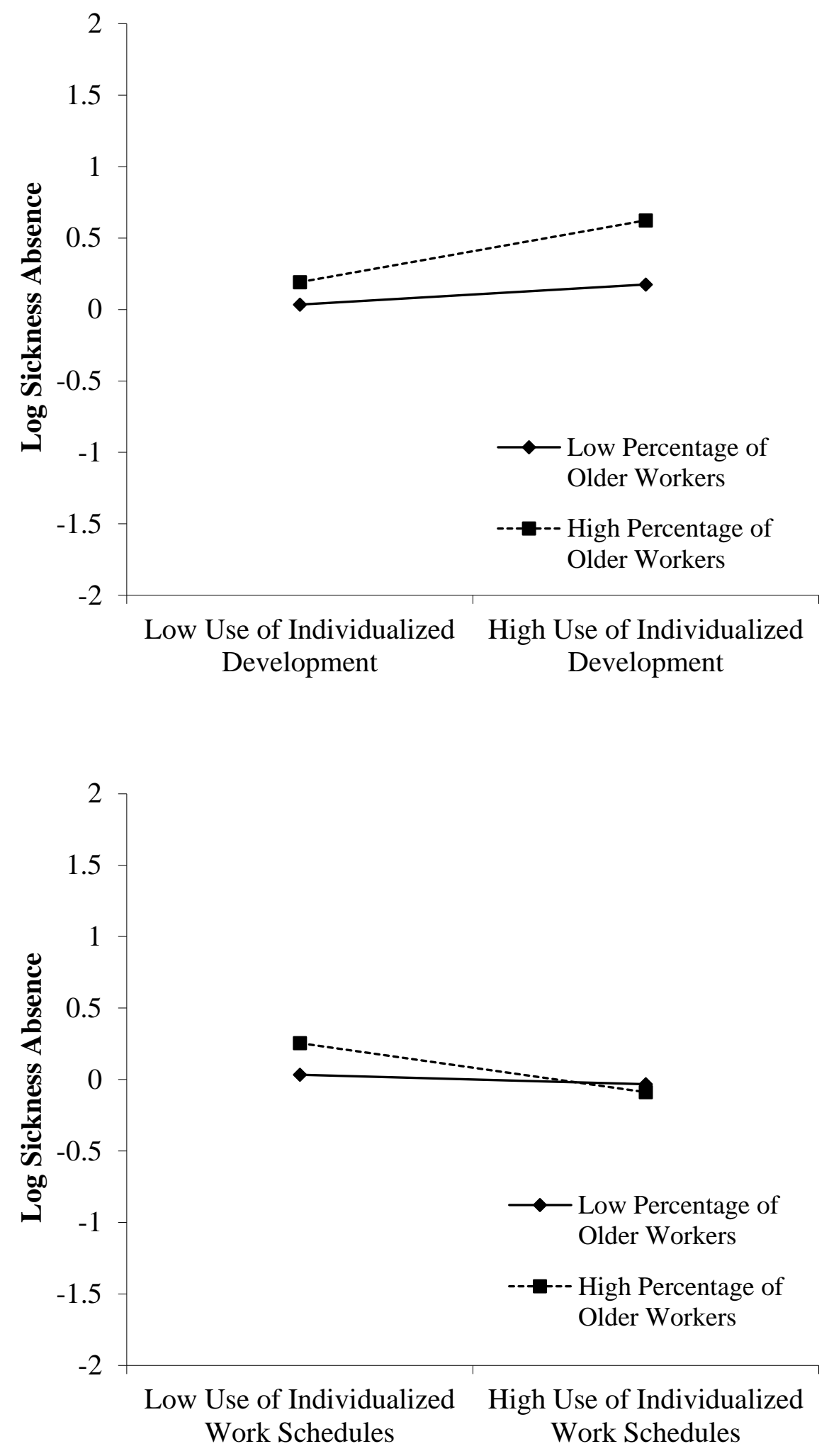

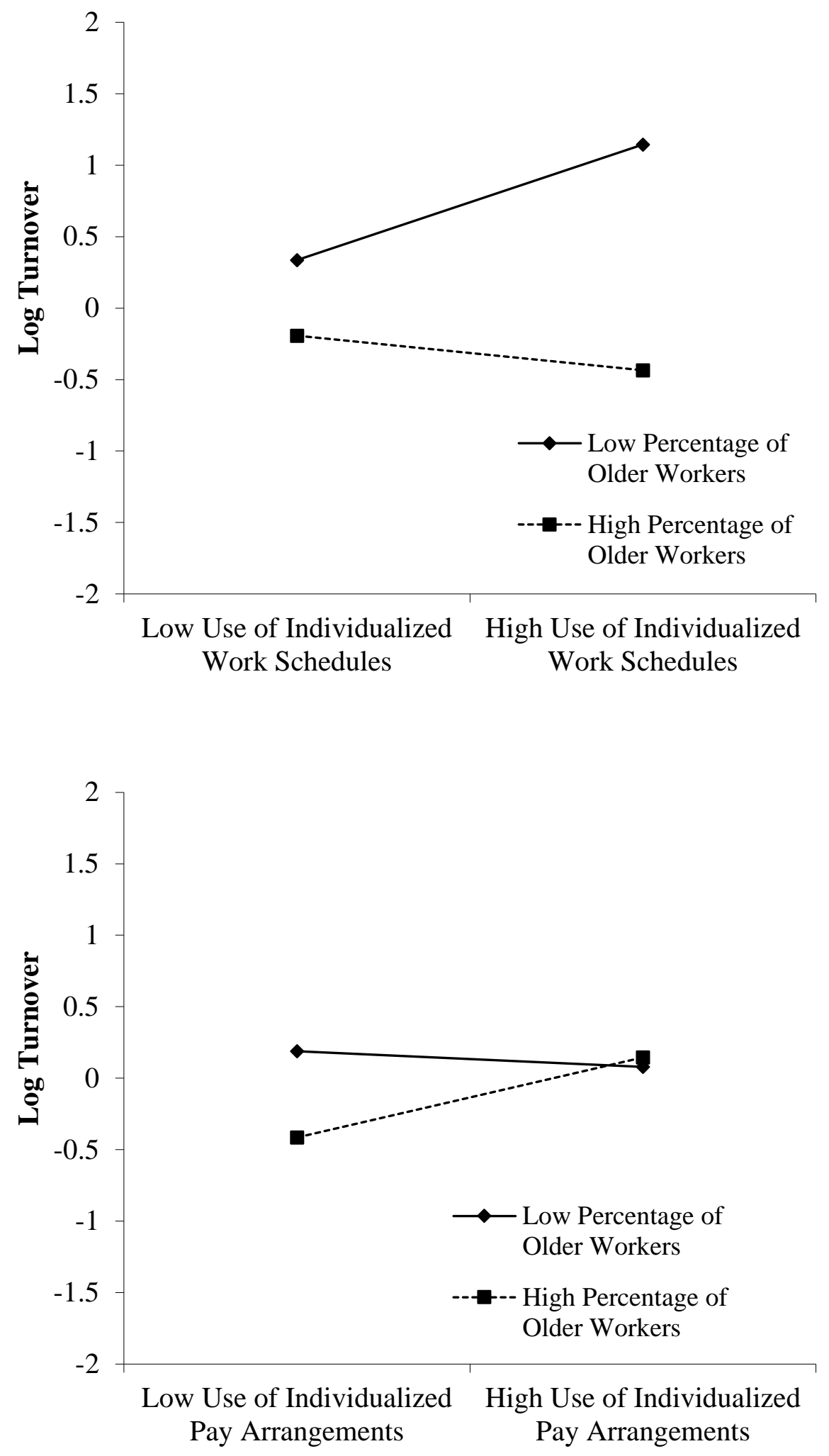